Vol. 2, No. 1, Desember 2021

\title{
PENYULUHAN MANAJEMEN USAHA PADA KELOMPOK USAHA BERSAMA (KUBE) DALAM RANGKA PEMBERDAYAAN MASYARAKAT PRASEJAHTERA DI DESA TAMAN SARI KECAMATAN GUNUNGSARI KABUPATEN LOMBOK BARAT
}

\author{
Emi Salmah \\ Fakultas Ekonomi dan Bisnis Universitas Mataram \\ emisalmah@unram.ac.id \\ Titi Yuniarti \\ Fakultas Ekonomi dan Bisnis Universitas Mataram \\ titiyuniarti@unram.ac.id \\ Endang Astuti \\ Fakultas Ekonomi dan Bisnis Universitas Mataram \\ e_astuti13@unram.ac.id \\ Eka Agustina \\ Fakultas Ekonomi dan Bisnis Universitas Mataram \\ ekaagustiani27@unram.ac.id
}

\section{Info Artikel}

Diterima:

10-11-2021

Disetujui:

30-12-2021

Diterbitkan:

30-12-2021

\begin{abstract}
Abstrak
Kegiatan penyuluhan dilakukan di Desa Taman Sari Kecamatan Gunungsari Kabupaten Lombok Barat, yang dihadiri oleh anggota Kelompok Usaha Bersama (KUBE) Dusun Medas Taman Sari. Penyuluhan bertujuan untuk memberikan motivasi kepada para anggota kelompok yang tergabung dalam Kelompok Usaha Bersama (KUBE) agar membuat catatan keuangan. Diharapkan setelah para anggota kelompok mengikuti pelatihan dan penyuluhan ini, mereka bisa menghitung penerimaan dan pengeluaran dari usaha yang dilakukan. Pada akhirnya timbul kesadaran dari anggota kelompok dalam hal pengelolaan keuangan, untuk meningkatkan usaha mereka agar lebih berdaya dan berkesinambungan.

Bentuk dari kegiatan adalah ceramah yang dilanjutkan dengan diskusi (Tanya jawab) secara interaktif untuk mempertajam pokok permasalahan yang disampaikan, yang dipandu oleh tim pengabdian. Dari hasil diskusi dapat diketahui bahwa ibu ibu yang tergabung dalam Kelompok Usaha Bersama (KUBE) di Desa Taman Sari sangat bersemangat/antusias dan mendukung kegiatan penyuluhan dan bimbingan
\end{abstract}


dengan pokok bahasan sebagaimana yang disampaikan oleh Tim Pengabdian kepada Masyarakat, Mereka pada umumnya baru tiga (3) tahun berusaha (Budidaya Jamur Tiram), setelah ada pembinaan atau bimbingan dari Yayasan Islamic Relief dengan memberikan bantuan/pinjaman dalam bentuk peralatan untuk membudidayakan Jamur Tiram.

Hasil kegiatan dan penyuluhan telah menambah pengetahuan dan wawasan mereka tentang bagaimana cara mengelola keuangan (mencatat uang yang masuk dan keluar) agar diketahui untung atau rugi usaha mereka. Untuk itu penyuluhan seperti ini perlu terus ditingktakan dan dikembangkan kearah yang lebih kreatif dan inovatif pada usaha lainnya secara intensif dan kontinyu, sehingga masyarakat dapat meningkatkan keterampilan dan pengetahuannya, dimana hal ini akan berdampak pada terjadinya perkembangan usaha ibu ibu yang tergabung dalam KUBE dan terjadi peningkatan pendapatan.

\section{Kata Kunci: Pengelolaan Keuangan. Administrasi Usaha, Kelompok Usaha Bersama, Desa Taman Sari.}

DOI: 10.29303 /abdimassangkabira.v2i1.91

\section{PENDAHULUAN}

Upaya pembangunan kesejahteraan sosial merupakan tanggung jawab pemerintah dan masyarakat. Pemerintah memiliki peran sentral dalam penyelenggaraan sosial, karena pemerintah memiliki kewajiban dan tanggung jawab untuk memenuhi hak hak dasar masyarakat. Disamping itu pemerintah juga memiliki peran sebagai pembuat kebijakan serta penyedia dan pengelola anggaran. Namun demikian dalam implementasi pembangunan kesejahteraan sosial tersebut, pemerintah tidak dapat bekerja sendiri tampa dukungan dan partisipasi masyarakat, Perguruan Tinggi dan lembaga lembaga lainnya.

Usaha mengatasi keluarga miskin melalui pemberdayaan yang telah dilaksanakan oleh pemerintah melalui berbagai program yang telah ada., salah satu usaha tersebut adalah program pengembangan usaha ekonomi produktif melalui kelompok usaha bersama (KUBE).

Usaha Ekonomi produktif (UEP) adalah bantuan sosial yang diberikan kepada kelompokm usaha bersama untuk meningkatkan pendapatan dan kesejahteraan sosial keluarga, Kelompok Usaha Bersama (KUBE) beranggotakan 5 sampai 20 kepala keluarga dari masyarakat miskin yang masuk dalam data terpadu.

Melalui program kelompok Usaha Bersama (KUBE), setiap orang saling berbagi pengalaman, saling berkomunikasi, saling kenal dan dapat 


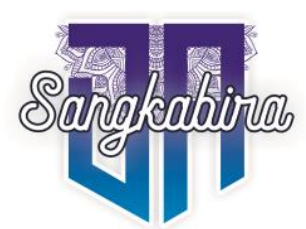

Vol. 2, No. 1, Desember 2021

menyelesaikan berbagai masalah dan kebutuhan yang dirasakan. Dengan adanya program KUBE, kegiatan usaha yang tadinya dilakukan sendiri sendiri, dikembangkan dalam kelompok sehingga setiap anggota dapat meningkatkan pengetahuan dan keterampilan dalam usaha ekonomi.

KUBE yang terdapat di Desa Mekar Sari Kecamatan Gunungsari ini, masyarakatnya masih belum antusias mengikuti program KUBE, disebakan banyak hal. Ada beberapa kelompok usaha yang tergabung dalam KUBE di Desa Taman Sari, antara lain; Usaha Budidaya Jamur Tiram, Madu Trigona Gula aren (Semut), kerajinan anyaman bambu dan Lidi. Usaha ini merupakan salah satu usaha yang tumbuh dan berkembang yang memanfaatkan potensi atau sumberdaya lokal yang umumnya berlangsung secara bertahap dan berkesinambungan. Pendidikan mereka rata-rata hanya tamat Sekolah Menengah Pertama (SMP) bahkan ada yang sama sekali tidak pernah sekolah. Keadaan ini menyebabkan pengelolaan usaha terutama berkaitan dengan keuangan tidak dilakukan secara sempurnah seperti usaha-usaha lainnya, namun dihadapkan pada kenyataan bahwa mereka belum mengelola keuangannya secara baik-baik dan rata-rata mereka tidak mempunyai simpanan (tabungan).

Jumlah masyarakat prasejahtera yang tergabung dalam KUBE di Desa Taman Sari sebanyak 110 orang. Mereka telah terbukti mampu memberikan kontribusi yang cukup besar bagi ekonomi rumahtangga. Berdasarkan masalah tersebut dan hasil observasi awal di Desa Taman Sari, menurut tim Pengabdian Kepada Masyarakat Fakultas Ekonomi dan Bisnis (FEB), Jurusan Ilmu Ekonomi dan Studi Pembangunan, merasa perlu mengadakan kegiatan pembinaan dalam pengelolaan usaha khususnya masalah keuangan, karena selama ini hasil penjualan dan input yang digunakan dalam proses produksi tidak dilakukan pencatatan/pembukuan sehingga dalam penentuan harga pokok biasanya tidak wajar. Oleh karena itu pelatihan dan penyuluhan ini dirasakan perlu agar dapat berusaha kearah yang lebih baik untuk usaha mereka dimasa akan datang. Kegiatan pelatihan ini juga akan memberikan kepada anggota kelompok tentang tehnik pemasaran agar mereka dapat memasarkan produknya dengan lebih baik dan berhasil guna.

\section{TUJUAN KEGIATAN}

Pada hakekatnya penyuluhan ini ditujukan pada Ibu - ibu yang tergabung dalam Kelompok Usaha Bersama (KUBE) di Desa Taman Sari Kecamatan Gunungsari, Kabupaten Lombok Barat, yang lebih banyak berperan dalam pelaksanaan usaha. Secara terinci tujuan dari kegiatan pelatihan / penyuluhan ini adalah;

a. Memberikan motivasi pada Ibu Ibu yang tergabung dalam KUBE untuk membuat catatan (pembukuan) mengenai penerimaan dan pengeluaran usaha mereka 
b. Memberikan tambahan pengetahuan tentang cara-cara menghitung penerimaan dan pengeluaran dari usaha yang dilakukan.

c. Memotivasi mereka agar mau menabung sebagian dari penghasilan mereka, agar tidak kesulitan modal pada saat mau membeli bahan baku.

\section{METODE PELAKSANAAN}

Kegiatan berbentuk penyuluhan dengan menggunakan metode ceramah umum, praktek membuat catatan keuangan, kemudian dilajutkan dengan diskusi, Tanya jawab dengan peserta yang dipandu oleh Tim Pengabdian Pada Masyarakat Fakultas Ekonomi dan Bisnis Universitas Mataram.

\section{MATERI MATERI YANG DISAMPAIKAN DALAM PELATIHAN: MATERI I. MANAJEMEN WIRASWASTA,}

Manajemen pada hakekatnya berhubungan dengan usaha untuk mencapai tujuan tertentu dengan menggunakan faktor-faktor produksi sebaik mungkin melalui orang-orang yang bekerja dalam usaha tertentu. Apabila kita ingin mencapai suatu tujuan tertentu diperlukan suatu pemutusan pemikiran, bagaimana mengelola tenaga yang tersedia, bagaimana mengelola bahan-bahan, alat-alat, bagaimana menggunakan waktu dan sebagainya. Pengetahuan tentang manajemen merupakan pedoman untuk berusaha, pedoman untuk melaksanakan dan bertindak, sekaligus sebagai dasar dalam pelaksanaan usaha yang produktif, sehingga dapat dicapai sebagaimana yang diharapkam.

Didalam menjalankan dan mengembangkan usahanya, pengusaha selalu berpegang pada prinsip-prinsip manajemen. Dalam jalan menggunakan prinsip-prinsip manajemen, para wiraswastawan akan dapat menghindari/mengurangi kesalahan-kesalahan, pemborosan-pemborosan dalam proses produksinya, serta dapat diperhitungkan kemungkinan usahanya.

Wirastawan pada dasarnya disebut juga sebagai manajer yang dapat merumuskan tujuan usahanya, dapat membuat penyusunan rencana produksinya, bagaimana memasarkan hasil produksinya, bagaimana melakukan pengendalian dan lain-lain.

Salah satu fungsi manajer adalah menyusun rencana yang membuat perumusan tujuan dan saran-saran serta tahapan kegiatan untuk mencapai tujuan usaha. Sebagai manajer mereka harus mampu menjalankan fungsifungsi manajemen seperti perencanaan. Pelaksanaan dan pengendalian.

Sebagai manajer wiraswasta harus mampu mengelola semua sumber, termasuk menggerakan orang lain dan atau bawahannya untuk mencapai tujuan usaha. Sebagai manajer mereka harus mampu 
menjalankan fungsi-fungsi manajemen seperti perencanaan, pelaksannan dan pengendalian.

Rencana merupakan tolok ukur untuk pengendalian pelaksanaan, untuk evaluasi dan dalam proses pelaksanaanya. Dalam hal tersebut di atas, seorang manajer sangat berperan dalam menentukan pendayagunaan sumber-sumber atau faktor-faktor produksi yang tersedia dengan menggunakan orang-orang yang bekerja dalam perusahaan. Dengan kata lain manajemen adalah ilmu dan seni bagaiman menggerakan orang lain untuk dapat menyelesaikan pekerjaan sehingga dapat mencapai tujuan yang telah ditentukan.

Disamping membuat perencanaan, seorang waraswatawan juga berfungsi untuk melakukan pengawasan, pengendalian, misalnya dalam hal pengendalian produksi. Setelah terlebih dahulu membuat perencanaan produksi yang baik dan mantap, maka dilanjutkan dengan tahapan pengendalian kegiatan produksi (proses produksi). Untuk dapat menghasilkan barang-barang yang baik sebagaimana yang telah direncakan dan diharapkan misalnya tepat jumlahnya, tepat waktunya, tepat biayanya dan lain-lain, maka diperlukan adanya pengendalian produksi.

Pengawasan adalah merupakan kegiatan yang dilakukan selama produksi berjalan. Untuk menghindari atau mengidentifikasi penyimpanganpenyimpangan dari rencana yang telah ditetapkan bersama. Pengawasan dan pengendalian diperlukan:

1. Agar pelaksanaan kegiatan tidak menyimpang dari rencana yang sudah ditentukan

2. Agar terhindar dari pemborosan, kebocoran, dan lain-lain

3. Agar kegiatan suatu program dapat tercapai dengan baik

\section{Pengertian Dan Sikap Kewiraswastaan}

Dalam pelaksanaan pembangunan di negara kita Republik Indonesia mengharapkan dan menuntut tersedianya masyarakat/penduduk yang selalu siap untuk berperan dalam pembangunan dengan memiliki kepribadian, kepercayaan pada diri sendiri, berani mengambil resiko, bergairah untuk berusaha/bekerja, mempunyai inisiatif dan semangat tinggi, ulet dan seterusnya. Dengan kata lain dalam pembangunan nasional kita membutuhkan manusia yang dapat berwiraswasta dan mempunyai jiwa wiraswasta.

Wiraswasta berasal dari:

Wira, artinya: Berani, perkasa, teladan dan pelopor

Swa, artinya: Sendiri

Sta, artinya Berdiri

Jadi secara harfiaah kewiraswastaan berarti suatu keberanian untuk berdiri di atas atau kemampuan untuk menjadi pelopor dalam melakukan suatu usaha secara mandiri. Dalam wawasan yang luas kewiraswastaan adalah suatu kepribadian, semangat, keahlian dan kemampuan dalam 
melakukan usaha secara mandiri dan memajukan diri sendiri serta lingkungannya.

Kewirawastaan berarti suatu kemampuan melakukan usaha, mengkombinasi dan mengelola sumberdaya yang tersedia untuk mendapatkan kemanfaatnan yang sebesar-besarnya. Seorang wiraswastawan mempunyai sifat kepeloporan, kemajuan selalu mau tumbuh dan berkembang, dan berusaha berdiri sendiri serta menciptakan lapangan kerja.

\section{Beberapa Sikap Kewiraswastaan Yang Harus Dimiliki}

\section{Kreatif}

Kewiraswastaan disamping harus pandai mencari kebutuhan, ia juga harus cekatan memenuhi kebutuhannya itu. Oleh karena itu ia harus memiliki daya pikir kreatif dan sikap mental kreatif. Apabila sikap kreatif tersebut memiliki dan diterapkan dalam usahanya maka berat kemungkinan wiraswastawan berhasil.

\section{Percaya pada diri sendiri}

Percaya pada diri sendiri mengandung makna bahwa individu itu potensi/kekuatan pada dirinya disamping kelemahan yang dimilikinya.

\section{Ulet, Tekun, Dan Rasional}

Seorang wirastawan tidak lekas putus asa menghadapi segala tantangan, memiliki kesabaran, tidak cepat merasa putus asa, selalu menggunakan pikiran sehat dalam mengambil keputusan dan tidak bersifat emosional.

\section{Berani Menanggung Resiko}

Apabila orang berusaha, baik pada waktu akan memulai usahanya maupun dalam proses pelaksanaan usahanya seringkali ia menghadapi resiko. Sebagai suatu resiko berusaha. Pengusaha selalu mencoba meminimumkan resiko ini dengan bermacam-macam cara seperti dengan melakukan ramalan-ramana, perencanaan yang mantap, asuransi dan lainlain.

\section{Berwawasan Masa Depan}

Wiraswasta harus berorientasi pada masa depan yang lebih baik, bukan hanya pada keadaan masa sekarang. Usaha-usaha yang dilakukan selalu mempunyai keterkaitan dengan masyarakat banyak terutama dari segi kepercayaan masyarakat.

Sebagai seorang manajer ia harus memahami manajemen, misalkan manajemen produksi. Manajemen produksi adalah suatu ilmu atau seni yang mengajarkan bagaimana menggunakan faktor-faktor produkai yang tersedia secara efisien dan efektif sehingga dapat dicapai tujuan yang telah ditetapkan.

\section{MATERI II: PENGELOLAAN PEMASARAN Pemasaran Dan Manajemen / Pengelolaan Pemasaran}




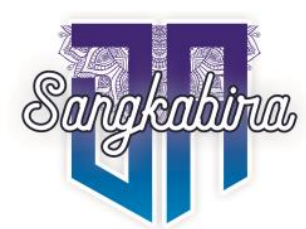

Vol. 2, No. 1, Desember 2021

Pemasaran merupakan salah satu kegiatan-kegiatan pokok yang dilakukan oleh perusahaan-perusahaan kecil atau perusahaan besar untuk mempertahankan kelangsungan usaha hidupnya untuk berkembang dan mendapatkan laba. Arti pemasaran sering dikacaukan dengan pengertianpengertian: (1) penjualan, (2) perdagangan (3) distribusi. Padahal istilahistilah tersebut hanyalah merupakan satu bagian dari kegiatan pemasaran secara keseluruhan. Proses pemasaran itu dimulai jauh sebelum barangbarang diproduksi dan tidsak berakhir dengan penjualan. Kegiatan pemasaran hatus dapat juga memberikan kepuasan kepada konsumen jika menginginkan usahanya berjalan terus, atau konsumen mempunyai pandangan yang baik terhadap perusahaan.

\section{Konsep Pemasaran Dan Pemahaman Konsumen}

Perusahaan kecil atau perusahaan besar yang sudah mengenal bahwa pemasaran merupakan faktor penting untuk mencapai sukses usahanya, akan mengetahui adanya cara dan falsafah yang terlibat didalamnya. Cara dan falsafah baru ini dinamakan konsep pemasaran. Sebagai falsafah bisnis, konsep pemasaran bertujuan memberikan kepuasan terhadap keinginan dan kebutuhan konsumen atau berorintasi pada konsumen. Hal ini sesuai azaz berbeda dengan falsafah bisnis terdahulu yang berorientasi pada produk dan penjualan. Apabila orientasi dari konsep-konsep tersebut bertolak dari produk/barang yang dihasilkan dan mamandang sebagai tugas perusahaan, adalah penjualan dan promosi untuk menstimulir volume penjualan yang menguntungkan, maka konsep pemasaran mengajarkan bahwa kegiatan pemasaran suatu organisasi/usaha harus dimulai dengan usaha mengenal dan merumuskan keinginan dan kebutuhan dari konsumenya. Kemudian usaha itu harus merumuskan dan menyusun suatu kebijaksanaan produk, harga, promosi dan distribusi setepat-tepatnya agar kebutuhan para konsumen dapat dipenuhi secara memuaskan. Secara definitive ditegaskan bahwa:

Konsep pemasaran adalah sebuah falsafah bisnis yang menyatakan bahwa pemuasan kebutuhan merupakan syarat ekonomi dan sosial bagi kelangsungan hidup perusahaan (baik perusahaan kecil maupun perusahaan besar).

\section{Tiga unsur pokok pemasaran adalah:}

1. Orientasi Pada Konsumen

2. Penyusunan Kegiatan Pemasaran Secara Integral

3. Kepuasan Konsumen

4. Arti Konsumen Akhir danPembeli Terakhir

5. Keterampilan Menjual

\section{MATERI III. PEMBUKUAN DAN ADMINISTRASI}

Tanpa disadari, dalam kehidupan sehari-hari sebenarnya kita telah melakukan pembukuan. seorang pengrajin gerabah atau ukir-ukiran membuat catatan bahan baku yang telah dipakai dan tenaga kerja yang 
telah dipekerjakan serta biaya-biaya lainnya yang telah dikeluarkan untuk membuat atau menghasilkan satu unit hasil kerja, maka pengerajin tadi pada dasarnya telah menerapkan teknik pembukuan secara sederhana.

Catatan yang dibuat oleh pengerajin dapat membantu dirinya mengetahui berapa pengorbanan yang dikelurakan untuk menghasilkan suatu barang yang dihasilkan, hal ini sangat penting atau mutlak dijadikan dasar penentuan harga jual yang wajar dari barang yang dihasilkan, bahkan dengan catatan tersebut perajin dapat memutuskan bahan-bahan yang akan dibeli atau dibutuhkan. informasi tentang harga didalamnya dapat dijadikan pedoman ketika membeli di bulan berikutnya dan lain-lain. demikian juga catatan belanja harian yang dibuat Ibu-ibu rumah tangga dapat dipakai sebagai informasi, sehingga dapat diputuskan apakah dia harus menambah atau mengurangi pengeluaran tertentu apakah dia harus menunda membeli alat-alat tertentu atau apakah dia harus menunda pembelian alat-alat tertentu atau apakah mungkin untuk menambah fasilitas bagian ruang temapt tinggalnya atau membuat catatan orangorang yang berhutang di warungnya, dari catatan tersebut pemilik warung dapat mengetahui siapa yang dianggap masih boleh dan pantas berhutang pada periode yang akan datang dan lain-lain.

Contoh di atas menggambarkan perlunya informasi keuangan sebaga dasar untuk melakukan tindakan tertentu. Walaupun informasi keuangan tersebut terbatas diperlukan untuk kepentingan sendiri, pada dasarnya kegiatan tersebut sudah dapat dikatakan akutansi walaupun masih dalam pengertian yang sederhana. Dapat disebut akutansi karena informasi keuangan sebagai salah satu unsure akutansi dipakai sebagai dasar pertimbangan untuk melakukan kegiatan tertentu atau mengambil keputusan tertentu.

Kejadian lain manakala seorang ketua kelompok perajin memiliki inisiatif membentuk suatu kelompok kerja sama dengan perajin-perajin lainnya, misalnya perajin ukiran dan perajin anyam-anyaman dikampungnya untuk membuka pusat kegiatan perajin semacam kios atau art shop secara swadaya. untuk itu ditunjuk seorang bendahara yang ditugaskan untuk mengumpulkan dana dan mencatat setiap sumbangan dari anggotanya. Kelompok perajin merasa perlu untuk menugaskan seseorang yang melakukan pencatatan karena ingin mengetahui berapa dana yang sudah terkumpul dan kapan pembanguan art shop dapat dimulai. Informasi ini penting karena pembangunan art shop dapat dimulai tergantung cukup tidaknya dana terkumpul.

Disamping itu juga perlu membuat laporan tentang biaya pembuatan art shop didepan anggota kelompoknya pada saat pembangunan art shop telah selesai. dalam hal ini sebenarnya kelompok perajin telah menjalankan akutansu karena adanya keperluan untuk memperoleh informasi keuangan untuk menentukan saat pelaksanaan pembangunan dan informasi untuk 
dasar penyusunan laporan pelaksanaan dan pembiayaan pembangunan art shop yang harus disampaika oleh ketua perajin tersebut.

Tentu saja akutansi tidak sesederhana contoh diatas, pengertian akutansi berkembang sehingga aplikasinya memerlukan penanganan yang khusus pula. Bahkan seorang yang akan menghubungkan pengertian akutansi dengan uang, pembukuan, tata buku, pajak kuitansi, profesi jabatan, akademi, fakultas ekonomi, komputer, rekening, laporan keuangan dan lainnya sesuai dengan tingkat pemahaman tentang arti akutansi.

\section{Pengertian Akutansi}

Adalah proses pengidentifikasian, mengukur dan melaporkan informasi ekonomi dalam sebuah perusahaan, sehingga dimungkinkannya adanya penilaian dan pengambilan keputusan bagi mereka yang menggunakan informasi tersebut.

Pengertian yang terkandung dalam definisi di atas adalah:

1. Bahwa akutansi merupakan proses yang terdiri dari identifikasi, pengukuran dan pelaporan informasi ekonomi.

2. Bahwa informasi ekonomi yang dihasilkan oleh akutansi diharapkan berguna dalam penilaian dan pengambilan keputusan mengenai perusahaan yang bersangkutan.

Tujuan akuntansi adalah menyajikan informasi ekonomi dari satu kesatuan ekonomi kepada pihak-pihak yang berkepentingan. Sedangkan yang dimaksudkan dengan kesatuan ekonomi adalah: badan usaha, Informasi ekonomi yang dihasilkan oleh akutansi berguna bagi pihak-pihak didalam perusahaan itu sendiri maupun pihak-pihak di luar perusahaan.

\section{MATERI IV. METODE PENGEMBANGAN USAHA}

Pengembangan usaha adalah upaya memperluas usaha yang ada seperti memperluas kios yang ada, menambah jenis dan jumlah barang dagangan, membuka kios sejenis di tempat yang lain, atau membuka usaha baru yang berbeda dengan usaha yang dikelola sebelumnya. anda telah memiliki kios kelontong karena menurut pengamatan anda dilokasi tersebut belum tersedia kios (toko) yang menjual alat tulis kantor, padahal disitu banyak orang membutuhkannya, maka kemudian anda membuka kios (toko) alat-alat tulis kantor, disamping anda telah memiliki toko kelontong,

Dalam upaya pengembangan usaha ini, ada aspek-aspek penting yang perlu memperoleh perhatian yaitu: aspek pasar, aspek teknis, aspek pengelolaan organisasi dan aspek ekonomi atau keuangan.

\section{ASPEK PASAR}

Pasar adalah lahan kehidupan usaha anda, pusatkan perhatian anda pada:

1. Barang yang dijual 
a. Barang jenis apa yang akan anda jual? alat tulis kantor, Sembilan bahan pokok, atau barang khusus seperti kue-kue dan anyaman.

b. Bagaimana jumlah dan peredarannya di pasar?

c. Mut dan mode yang paling banyak laku

d. Bagaimana tingkat harga dan permintaannya? misalnya salah satu jenis produk yang akan dijual adalah shampo:

- Ada berbagai jenis dan merk shampo mulai dari yang bungkusan kecil sampai dengan yang bungkusan besar.

- Bagaimana peredarannya di pasar? cepat atau lambat, banyak atau sedikit?

- Kwalitas dan model apa yang paling disenangi? bungkusan atau botolan?

- Berapa permintaan dan harga yang biasa diperlukan oleh pembeli?

2. Calon Konsumen

Tentu saja calon konsumen yang utama adalah masyrakat disekitar kios anda dan mereka sering melintas disekitar kios anda. Untuk memperoleh informasi tentang siapa calon konsumen dalam kaitannya dengan rencana pengembangan usaha ini, ada beberapa cara yang dapat dilakukan, misalnya melalui masyrakat disekitar tempat anda berjualan. Anda perlu mempelajari: berapa jumlah penduduk sekitar tempat jualan anda, bagaimana status sosial ekonomi mereka? apakah mereka kaya, golongan menengah atau golongan bawah yang banyak. informasi tersebut anda dapat memperoleh dari RW (Rukun Warga) atau kelurahan ataupun kecamatan diwilayah usaha baru yang anda rencanakan. Disamping itu informasi juga bisa diperoleh dari orangorang atau calon pembeli yang sering melintas disekitar tempat usaha anda. Hal ini bisa dilakukan jika pengembangan usaha dimaksudkan untuk menambah jumlah dan jenis barang dagang pada usaha kios yang telah ada.

3. Taksiran jumlah permintaan barang

Jika informasi tentang siapa calon konsumen yang telah diperoleh, selanjutnya ada beberapa cara untuk mengetahui perkiraan jumlah permintaan barang:

a. Mempelajari pengalaman penjualan yang telah ada. Anda dapat melihatnya dari catatan hasil penjualan bulanan atau tahunan.

b. Menurut jumlah dan status sosial ekonomi penduduk. Berapa jumlah penduduk diwilayah tempat usaha anda? bagaimana status ekonominya, kaya, menengah, atau golongan miskin (bawah). Berapa KK penduduk yang bertempat tinggal disekitar tempat jualan anda. Mereka inilah yang mungkin akan menjadi pembeli utama yang dapat anda penuhi. 
c. Apakah ada pesaing, usaha sejenis yang ada di dekat tempat usaha anda, siapa dan berapa banyak pesaing tersebut. Usaha sejenis disekitar tempat usaha atau calon tempat pengembangan usaha baru, adalah pesaing yang harus anda kendalikan. Anda harus memeperhatikan dengan cermat.

4. Cara Pelayanan

a. Ramah dan akrab dengan pembeli

b. Keluwesan dalam tawar menawar dengan pembeli.

\section{ASPEK TEKNIS}

Kalau ketiga hal tersebut diatas (calaon pembeli, permintaan barang dan keadaan pesaing serta cara pelayanan sudah anda pahami secara cermat, langkah-langkah selanjutnya adalah memperhitungkan:

a. Berapa kemampuan volume usaha yang diinginkan

b. Darimana barang dagangan diperoleh

c. Perlengkapan apa yang diperlukan

d. Dimana lokasinya

e. Bagaimana mempromosikan usaha

Volume usaha disebut juga omzet usaha, artinya adalah besarnya nilai penjualan pada waktu tertentu, misalnya satu hari, satu minggu, satu bulan atausatu tahun. pada umumnya para pengusaha memperhitungkan pada setiap akhir bulan. Bag pengembangan usaha yang telah ada, besarnya omzet usaha yang diinginkan didasarkan pada penggalaman penjualan selama ini

\section{HASIL KEGIATAN}

Peserta penyuluhan adalah Ibu ibu yang melakukan usaha budidaya Jamur Tiram yang tergabung dalam Anggota KUBE TENGKONG MEDAS. Usaha Jamur Tiram dimulai Tahun 2017 dengan adanya bantuan dana dan tehnis dari ISLAMIC RELIEF (Kumpulan beberapa Negara Timur Tengah), yang memberikan bantuan/ pinjaman awal berupa peralatan, seperti kompor, panci, bak plastik besar, cangkul, terpal, bambu tali dan peralatan lain untuk memulai usaha jamur. Bantuan/ pinjaman tersebut akan dikembalikan sekali seminggu saat panen sebesar Rp 218.000, kalau tidak mendapatkan hasil (gagal panen) bisa diangsur minggu berikutnya. Mulai tanam bibit sampai mulai bisa panen perdana butuh waktu 1,5 bulan ( 6 minggu) lama panen 4 (empat) bulan juga bisa lebih 4 bulan.

Olahan jamur tiram sekarang sudah beraneka macam antara lain: sate jamur, kripik jamur dan bakso jamur. Hasil jamur tiram tidak hanya memenuhi kebutuhan pasar setempat, ada juga pemesan dari luar Taman Sari dalam jumlah besar/ banyak. Kadang Kadang persediaan jamur tidak dapat memenuhi semua permintaan dari luar, karena masih terbatasnya jumlah produksi mereka. 
Ibu-Ibu yang tergabung dalam KUBE, sebelumnya mereka bekerja serabutan, ada yang sebagai pemecah batu, angkut pasir dan penjual bakulan. Setelah mereka berusaha jamur tiram kondisi ekonomi rumah tangga mereka, karena usaha mereka menjanjikan / prospeknya sangat bagus. Walaupun mereka tidak melakukan mencatatan keuangan, mereka merasakan ada perubahan dalam kondisi ekonomi keluarga, karena usaha jamur tiram bisa panen 3 kali seminggu.

Dengan adanya kegiatan pelatihan / penyuluhan ini, para peserta anggota KUBE mendapatkan pengetahuan yang sangat mendasar mengenai aspek aspek yang sangat dibutuhkan dalam manajemen keuangan/pembukuan, meliputi pengetahuan mengenai 1). Manajemen Wiraswasta.2). Tehnik pemasaran, 3). Pembukuan dan Administrasi dan 4). Metode pengembangan Usaha.

Kegiatan pengabdian pada masyarakat ini dikatakan berhasil, dilihat dari banyaknya peserta yang hadir dan semangat serta antusiasnya mereka dalam mengajukan pertanyaan pada saat sesi diskusi. Hampir semua peserta ikut bertanya dan mengemukakan permaslahan yang mereka hadapi sekarang, seperti belum adanya catatan keuangan yang masuk dan keluar serta masih digabungkannya uang usaha dan uang rumah tangga, sehingga sulit diketahui apakah mereka mengalami untung atau rugi. Mereka merasakan adanya keuntungan dari usaha, karena mereka bisa mengembangkan usahanya kearah yang lebih baik dari sebelumnya, dan bisa dilihat dari kepemilikan asset rumahtangga mereka yang sudah bertambah dan lebih berkualitas dari sebelumnya. Peserta dengan semangat dan antusiasnya mengikuti acara ini sampai selesai.

Dari hasil diskusi para peserta bernia untuk mulai mencatat uang yang masuk dan keluar sehingga diketahui apakah mereka memperoleh kuntungan atau mengalami kerugian. Disamping itu adanya keingin mereka untuk memisahkan uang rumahtangga dengan uang usaha, agar usahanya berjalan dengan baik dan sukses.

Kegiatan pelatihan/penyuluhan dapat terlaksana dengan baik dan lancr, tidak lepas dari adanya factor pendorong, yakni peserta penyuluhan dalam melaksanakan kegiatn ini merupaka modal utama.

\section{KESIMPULAN DAN SARAN}

\section{Kesimpulan}

1. Dengan memahami dan mengetahui arti dan manfaat administrasi usaha, mereka akan dapat mengurangi atau terhindar dari kesalahankesalahan yang pernah mereka lakukan selama ini, disamping itu mereka juga akan dapat mengetahui keberhasilan dari usaha yang mereka lakukan.

2. Dengan administrasi dan pembukuan yang rapi dan baik, akan dapat memberikan kemudahan bagi mereka untuk melakukan suatu 
perencanaan dimasa akan datang dan dapat memperbaiki kesalahan yang pernah mereka lakukan.

3. Perencanaan dan pengelolaan keuangan yang baik sebagai alat kendali yang dapat mengingatkan untuk melakukan sesuatu yang terbaik bagi usaha yang mereka jalani.

\section{Saran-Saran}

1. Kegiatan penyuluhan ini baru diikuti oleh sebagian kecil dari ibu ibu yang tergabung dalam kelompok Usaha Bersama (KUBE) di Desa Taman Sari, dirasa perlu untuk melaksanakan kegiatan yang bersifat praktek lapangan dalam arti penyuluhan yang disertai praktek (Simulasi) dengan jumlah peserta yang lebih banyak dan dalam waktu yang relatif lama sehingga masyarakat khususnya para ibu ibu yang tergabung dalam KUBE ini, mengetahui secara langsung kegiatan penyuluhan.

2. Keadaan ini bisa terlaksana bila didukung oleh dana yang lebih memadai dan mengadakan kerjasama dengan Departemen Perdagangan dan Perindsutrian (Deperindag) Kabupaten Lombok Barat, agar pada kegiatan selanjutnya dapat ditindaklanjuti dengan pelaksanaan pendidikan dan pelatihan serta pembinaan terhadap obyek yang sama pada kegiatan selanjutnya dimasa mendatang.

\section{UCAPAN TERIMA KASIH}

Tim pengabdian kepada masyarakat mengucapkan terima kasih kepada Fakultas Ekonomi dan Bisnis Universitas Mataram yang telah mendanai kegiatan ini melalui dana PNBP dan kepada Kepala Desa Taman Sari Kecamatan Gunungsari yang telah memberikan izin dan fasilitas ruangan/aula desa sebagai tempat pelaksaan kegiatan. Tidak lupa tim pengabdian mengucapkan terima kasih kepada ibu ibu anggota Kelompok Usaha Bersama (KUBE) Tengkong Medas yang telah meluangkan waktunya untuk mengikuti kegiatan ini dari awal sampai akhir secara antusias. 